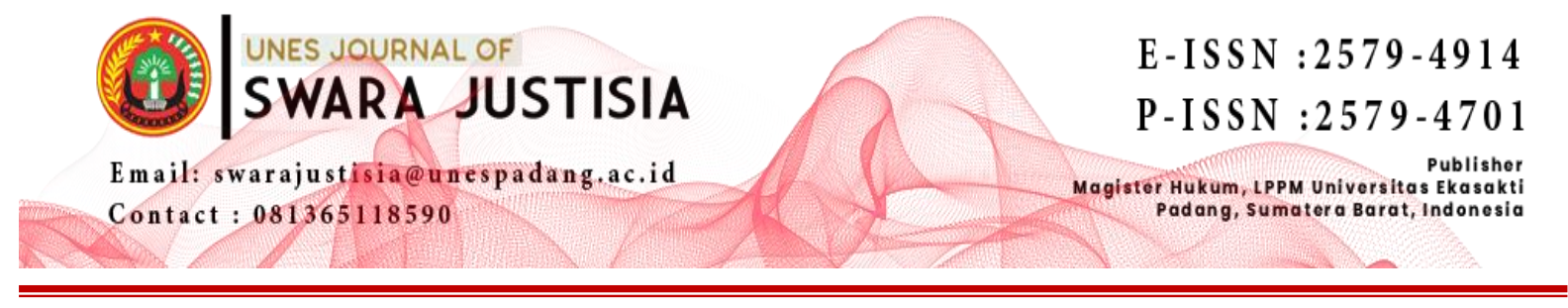

\title{
PERLINDUNGAN HUKUM TERHADAP KONSUMEN DALAM PRAKTIK PENGOBATAN TRADISIONAL TANPA IZIN DI NAGARI SURANTIH KECAMATAN SUTERA KABUPATEN PESISIR SELATAN
}

\author{
Fajar Adil Oka Masri \\ Program Magister Ilmu Hukum, Universitas Ekasakti, Padang, Indonesia \\ Email: ajaradiloka63@gmail.com
}

\begin{abstract}
ABSTRAK
Hukum perlindungan konsumen merupakan bagian dari hukum konsumen yang memuat asasasas pengaturan dan juga mengandung sifat-sifat yang melindungi kepentingan konsumen. Hukum konsumen dapat didefinisikan sebagai keseluruhan asas dan aturan yang mengatur hubungan dan masalah dengan penyediaan dan penggunaan barang dan/atau jasa antara penyedia dan pengguna dalam kehidupan bermasyarakat. Jenis penelitian ini adalah penelitian deskriptif analitik. Pendekatan yang digunakan adalah pendekatan yuridis normatif yang didukung oleh pendekatan yuridis empiris, data yang digunakan adalah data sekunder sebagai data utama dengan data primer sebagai data pendukung yang dikumpulkan melalui studi kepustakaan dan studi lapangan dengan teknik wawancara. Data tersebut kemudian dianalisis secara kualitatif dan disajikan dalam bentuk deskriptif kualitatif. Berdasarkan hasil penelitian dapat disimpulkan bahwa: 1) Perlindungan hukum bagi konsumen adalah segala upaya yang menjamin kepastian hukum untuk memberikan perlindungan kepada konsumen dan diharapkan dapat digunakan sebagai benteng untuk menghilangkan tindakan sewenangwenang yang merugikan pelaku usaha saja. demi perlindungan konsumen. Kewenangan akan mengakibatkan ketidakpastian hukum. perlindungan konsumen belum dilakukan oleh pelaku usaha dengan baik, tidak memiliki izin dari dinas kesehatan dan tidak memiliki standar pengobatan yang baik. 2) Pengawasan Pemerintah Nagari Surantih terhadap perlindungan obat tradisional dilakukan dengan melakukan pemantauan dan pengawasan jika ada pelanggaran yang dilakukan oleh pelayanan pengobatan tradisional. Namun, kelemahan pemerintah tidak menutupinya dan memaksa para praktisi pengobatan tradisional untuk segera mendapatkan izin agar pengobatan tersebut memiliki standar pengobatan yang benar dari dinas kesehatan setempat. 3) Obat tradisional sangat bermanfaat bagi masyarakat karena dengan adanya obat tradisional masyarakat dapat berobat dengan biaya yang sangat murah dan sudah terbukti pengobatannya manjur dan bahan yang digunakan sangat aman, namun dampaknya juga ada. seperti kasus yang dijelaskan diatas dimana pasien/penderita merasa pengobatan yang dilakukan membuat penyakitnya berkembang bahkan merasakan penyakit lainnya juga.
\end{abstract}

Kata Kunci: Perlindungan Hukum, Praktik Pengobatan Tradisional Tanpa Izin

\section{PENDAHULUAN}

Kesejahteraan dan kemakmuran rakyat di bidang pelayanan kesehatan tradisional, diperlukan terciptanya hubungan yang sehat antara para pihak yaitu pelaku usaha pengobatan 
tradisional dengan pasien. Produsen atau pelaku usaha merupakan salah satu komponen yang turut bertanggung jawab dalam mengusahakan tercapainya kesejahteraan rakyat itu. Dunia usaha harus mampu menghasilkan berbagai barang dan/atau jasa yang dapat meningkatkan kesejahteraan masyarakat banyak dengan pemastian terhadap mutu, jumlah yang mencukupi, serta keamanan pada pemakai barang dan/atau jasa yang diedarkan di pasar (Janus Sidabalok, 2010: 83).

Saat ini banyak pelaku usaha pengobatan tradisional di Indonesia, menawarkan pelayanan pengobatan tradisional dan obat tradisional. Untuk menarik minat masyarakat tidak jarang pelaku usaha pengobatan tradisional ini memasang iklan yang berlebihan agar pasien datang berobat. Padahal ini sangat merugikan konsumen apabila pelayanan yang diberikan tidak sesuai dengan iklan yang ditawarkan.

Kesepakatan antara pelaku usaha pengobatan tradisional dengan pasien sebagai konsumen jasa untuk memakai jasa, yaitu keahlian dalam pengobatan tradisional baik secara lisan maupun tertulis. Maka adanya hubungan hukum pasien dengan pelaku usaha pengobatan tradisional adalah hubungan hukum antara konsumen dengan penyedia jasa. Hubungan hukum tersebut dapat dikatakan hubungan kontraktual. Masyarakat yang menggunakan keahlian jasa pengobatan tradisional dapat disebut sebagai konsumen jasa.

Pengobatan tradisional merupakan salah satu cabang pengobatan alternatif yang bisa didefinisikan sebagai cara pengobatan yang dipilih oleh seseorang bila cara pengobatan konvensional tidak memberikan hasil yang memuaskan (Asmino, 1995: 177). Pengobatan tradisional adalah pengobatan dan atau perawatan dengan cara, obat, dan pengobatannya yang mengacu pada pengalaman dan keterampilan turun temurun dan diterapkan sesuai dengan norma yang berlaku dalam masyarakat. Pengobatan tradisional (batra) adalah seseorang yang diakui dan dimanfaatkan oleh masyarakat sebagai orang yang mampu melakukan pengobatan secara tradisional.

Obat tradisional adalah bahan atau ramuan yang berupa bahan tumbuhan, bahan hewan, bahan mineral, sediaan galenik atau campuran dari bahan-bahan tersebut, yang secara tradisional telah digunakan untuk pengobatan berdasarkan pengalaman. Obat tradisional secara turun-temurun telah digunakan untuk kesehatan berdasarkan pengalaman. Obat tradisional telah digunakan oleh berbagai aspek masyarakat mulai dari tingkat ekonomi atas sampai tingkat bawah, karena obat tradisional mudah didapat, harganya yang cukup terjangkau dan berkhasiat untuk pengobatan, perawatan dan pencegahan penyakit ${ }^{1}$.

Nagari Surantih merupakan salah satu nagari di Pesisir Selatan Sumatera Barat yang memiliki kultur adat budaya salingka Nagari berbeda dari nagari lain dalam kehidupannya. Salah satu kultur budaya dalam aspek kehidupan yang masih dikenal saat ini adalah tentang sistim pengobatan ramuan tradisional. Pengetahuan tentang pengobatan diturunkan oleh orang tua di nagari (niniak). Resep pengobatan diwariskan dan diterima secara lisan dari orang tua terdahulu dan terus dipakai serta diwariskan kepada anak cucunya. Walau asal usul ramuan pengobatan ini didapat dengan cara tidak tertulis namun masih dilazimkan pemakaiannya dimasyarakat.

\footnotetext{
${ }^{1}$ Dirjen POM RI. Petunjuk Pelaksanaan Pembuatan Obat Tradisional Yang Baik (CPOTB). Departemen Kesehatan Republik Indonesia. Jakarta, 1994.
} 
Pengertian perlindungan hukum adalah suatu perlindungan yang diberikan terhadap subyek hukun dalam bentuk perangkat hukum baik yang bersifat preventif maupun yang bersifat represif, baik yang tertulis maupun tidak tertulis. Dengan kata lain perlindungan hukum sebagai suatu gambaran dari fungsi hukum, yaitu konsep dimana hukum dapat memberikan suatu keadilan, ketertiban, kepastian, kemanfaatan dan kedamaian. ${ }^{2}$

\section{METODE PENELITAN}

Penelitian ini merupakan penelitian hukum dengan spesifikas deskriptif analitis. Pendekatan yang akan digunakan dalam penelitian ini adalah pendekatan yuridis normatif sebagai pendekatan utama dan didukung dengan pendekatan yuridis empiris. Data yang digunakan adalah data sekunder dan data primer yang diperoleh melalui studi lapangan dan studi kepustakaan yang kemudian di analisis secara kualitatif dan disajikan dalam bentuk deskriptif kualitatif.

Teknik pengumpulan data yang digunakan dalam usulan penelitian ini difokuskan untuk data skunder dan data primer yang mana terdiri dari:

a. Data sekunder dikumpulkan melalui studi kepustakaan (library Research) dan studi dokumen. Data sekunder berupa peraturan dan norma hukum kesehatan dan perlindungan konsumen, buku-buku, makalah, jurnal, artikel internet yang berhubungan dengan perlindungan hukum bagi pasien sebagai konsumen jasa pelayanan kesehatan di bidang pengobatan tradisional dan lain sebagainya.

b. Data primer akan dikumpulkan melalui penelitian lapangan yang mana penelitian ini guna uantuk melegkapi dan menambah kekurangan data yang ada dalam data skunder. Pengumpulan data menggunakan tehnik observasi dan wawancara secara mendalam. Partisipan observation dipilih untuk dapat menjalin hubungan komunikasi dan interaksi yang baik dengan para informan pada saat pengobatan tradisional ini dari awal sampai akhir pelaksanaan.

\section{PEMBAHASAN}

\section{A. Perlindungan Hukum Terhadap Konsumen Dalam Pratik Pengobatan Tradisional}

Perlindungan konsumen adalah segala upaya yang menjamin adanya kepastian hukum untuk memberi perlindungan kepada konsumen. Rumusan tersebut diharapkan dapat dijadikan sebagai benteng untuk meniadakan tindakan sewenang-wenang yang merugikan pelaku usaha hanya demi untuk kepentingan perlindungan konsumen. Kewenang- wenangan akan mengakibatkan ketidakpastian hukum.

Oleh karena itu, agar segala upaya memberikan jaminan kepastian hukum, ukurannya secara kualitatif ditentukan dalam UUPK dan undang-undang lainnya yang juga dimaksudkan dan masih berlaku untuk memberikan perlindungan konsumen, baik dalam Hukum Privat (Perdata) maupun bidang Hukum Publik.

Pengobatan tradisional yang dilakukan (Y) sudah cukup lama dan sudah banyak berhasil dalam menangani penyakit dari masyarakat namun dari kasus yang telah diterangkan sebelumnya bahwa kasus ini bermula pada saat korban $(\mathrm{X})$ datang ke pelaku usaha (Y) dengan tujuan untuk mengobati penyakit pada tubuhnya yang merasa sakit

\footnotetext{
${ }^{2}$ Rahayu, , Pengangkutan Orang, etd.eprints.ums.ac.id. Peraturan Pemerintah RI, 2009
} 
kepala, badan dan perut, tetapi pada satu waktu (X) datang kembali ke (Y) meminta pertanggungjawabannya sebagai pelaku usaha, karena (X) merasa belum sehat malah merasakan sakit bertambah. Hingga akhirnya kasus ini dibawa ke pihak pimpinan nagari yaitu kepala kampung dan wali nagari.

Mengenai kegiatan usaha pengobat tradisional memang sejak awal pelaku usaha (Y) sudah tidak memiliki itikad baik untuk menjalankan kegiatan praktik pengobatan tradisionalnya. Permasalahan ini sudah terlihat di mana (Y) yang belum melakukan proses pengurusan perizinan praktik usaha tetapi sudah menyebarkan kegiatan usahanya lewat orang lain melalui mulut kemulut dan juga telah menjalankan praktik pengobatan. Jelas di sini, bahwa (Y) memang tidak melakukan kewajibannya sesuai ketentuan Pasal 7 UUPK, di mana ia tidak memiliki itikad baik dalam melakukan kegiatan usahanya dan tidak memberikan informasi yang benar, jelas, dan jujur mengenai kondisi dari jasa pengobatannya. Sedangkan, berdasar pada Pasal 4 UUPK, (X) selaku konsumen pemanfaat jasa pengobatan tradisional memiliki hak atas kenyamanan, keamanan, dan keselamatan dalam mengkonsumsi barang dan/atau jasa, hak untuk memilih barang serta mendapatkan barang-barang tersebut sesuai dengan nilai tukar dan kondisi serta jaminan yang dijanjikan, hak untuk atas informasi barang yang benar dan jelas dan jujur mengenai kondisi dan jaminan atas barang dan/atau jasa yang dibelinya, akan tetapi hak- hak itu tidak diperolehnya secara penuh dari pelaku usaha (Y).

Di sinilah permasalahan yang sering memunculkan terjadinya sengketa antara konsumen dan pelaku usaha, di mana antara kepentingan konsumen berbenturan dengan kewajiban dari pelaku usaha. Permasalahan yang muncul dari kelalaian yang dilakukan oleh pelaku usaha/pengobat tradisional (Y) adalah terkait dengan:

1. Masalah periklanan yang berkaitan dengan isi Pasal 10 Undang- undang Perlindungan Konsumen, di mana diterangkan dalam ketentuan tersebut pelaku usaha dalam menawarkan barang dan/atau jasa yang ditujukan untuk diperdagangkan dilarang menawarkan, mempromosikan, mengiklankan atau membuat pernyataan yang tidak benar atau menyesatkan mengenai kondisi, tanggungan, jaminan, hak atau ganti rugi atas suatu barang dan/atau jasa. Namun, dalam kasus ini pelaku usaha (Y) sudah menyebarkan tempat usaha dan jenis usahanya lawan masyarakat yang satu kepada yang lainnya dengan menawarkan sesuatu yang dapat menyesatkan konsumen, karena tidak memberitahukan kondisi yang sebenarnya bahwa pelaku usaha/pengobat tardisional. Hal ini tentu sudah melanggar ketentuan Pasal 10 huruf c, di mana pelaku usaha/pengobat tradisional (Y) tidak memberitahukan kondisi sebenarnya yang dapat membawa dampak menyesatkan bagi konsumen.

2. Mengenai perizinan tempat praktik pengobatan pelaku usaha/pengobat tradisional (Y), di mana ia sudah membuka tempat praktik dan menerima konsumen padahal belum melakukan proses perizinan dari Dinas Kesehatan Kabupaten Pesisir Selatan. Hal ini jelas telah bertentangan dengan Kepmenkes No. 1076 Tahun 2003 dalam Pasal 14 Ayat (1), dimana dinyatakan bahwa pengobat tradisional yang melakukan pekerjaan/praktik sebagai pengobat tradisional harus memiliki STPT dan SIPT. Apabila melanggar ketentuan diatas, maka sanksi yang diterima oleh pelaku usaha/pengobat tradisional (Y) sesuai ketentuan Pasal 33 Ayat (2) Kepmenkes No. 1076 Tahun 2003 dapat berupa: 
teguran lisan, teguran tertulis, pencabutan STPT atau SIPT, penghentian sementara kegiatan, dan larangan melakukan pekerjaan sebagai pengobat tradisional.

Sedangkan untuk pertanggungjawaban pelaku usaha, dapat dilihat dalam Pasal 19 Undang-undang Perlindungan Konsumen, di mana terhadap kasus ini dapat dikualifikasikan secara perdata dan pidana. Tanggung jawab pelaku usaha pengobatan tradisional (Y) yang melakukan kelalaian dalam praktik usahanya hanya sebatas apa yang telah ditetapkan dalam Pasal 19 Undang-undang Perlindungan Konsumen, yakni berupa tanggung jawab secara perdata dan secara pidana, di mana konsumen yang merasa dirugikan $(\mathrm{X})$ dapat meminta ganti rugi dalam bentuk, pengembalian uang atau pengantian barang dan/atau jasa yang sejenis atau setara nilainya, atau perawatan kesehatan dan/atau pemberian santunan. Terhadap tanggung jawab pidananya, pemberian sejumlah ganti rugi tersebut ternyata tidak menghapuskan kemungkinan adanya tuntutan pidana yang berdasarkan pada pembuktian mengenai unsur kesalahannya. Sehingga korban (X) masih dapat menuntut secara pidana ke pelaku usaha (Y), walaupun ia sudah menerima ganti rugi berupa pengembalian uang jasa yang setara nilainya.

Pertanggungjawaban secara perdata dapat dimintakan kepada pelaku usaha (Y) apabila konsumen (X) mengajukan tuntutan ganti kerugian berdasarkan wanprestasi atau tuntutan ganti kerugian yang berdasarkan perbuatan melawan hukum. Dalam kasus ini, tuntutan ganti rugi yang didasarkan perbuatan melawan hukum lebih tepat untuk digunakan daripada tuntutan berdasarkan wanprestasi. Hal ini dikarenakan bentuk prestasi yang diperjanjikan oleh kedua pihak tidaklah jelas, di mana tidak memuat syarat sahnya perjanjian yang sesuai dengan Pasal 1320 KUHPerdata mengenai objek apa yang diperjanjikan diantara kedua pihak karena didalam pengobatan tradisional tidak memuat standar pengobatan seperti halnya dalam pengobatan konvensional (kedokteran). Untuk dapat menuntut ganti kerugian berdasarkan perbuatan melawan hukum harus dipenuhi unsur-unsur sebagai berikut:

1. Perbuatan itu harus melawan hukum

Perbuatan melawan hukum tidak lagi hanya sekadar melanggar undang-undang, melainkan perbuatan melawan hukum tersebut dapat berupa: Melanggar hak orang lain, bertentangan dengan kewajiban hukum si pembuat; berlawanan dengan kesusilaan baik, berlawanan dengan sikap hati-hati yang seharusnya diindahkan dalam pergaulan masyarakat terhadap diri atau benda orang lain. Dalam hal ini kegiatan usaha yang dijalankan oleh pelaku usaha (Y) telah bertentangan dengan ketentuan Undang-undang Perlindungan Konsumen dan Kepmenkes 1076 Tahun 2003, karena (Y) seperti yang telah diterangkan sebelumnya telah melanggar Pasal 10 huruf c Undang-undang Perlindungan Konsumen mengenai periklanan yang menyesatkan dan Pasal 14 Ayat (1) Kepmenkes 1076 Tahun 2003 mengenai masalah pendaftaran/perizinan tempat praktik usaha yang bermasalah.

2. Ada kerugian;

Pasien (X), selaku konsumen pemanfaat jasa pengobatan tradisional. Ini merupakan kerugian secara imaterriil yang diterima oleh (X). Sedangkan terhadap uang jasa yang telah dikeluarkan oleh $(\mathrm{X})$ dalam upayanya untuk mengobati penyakit ternyata tidak terwujud, dan pada akhirnya uang itu terbuang secara percuma. Ini adalah kerugian 
material yang diderita oleh (X) selaku konsumen pemanfaat jasa pengobatan tradisional.

3. Ada hubungan sebab akibat (kausal);

Jelas terdapat hubungan sebab akibat antara konsumen (X) dengan pelaku usaha (Y) dalam kasus ini dalam hubungannya antara kerugian yang diterima oleh (X) dengan tindakan yang dilakukan oleh (Y).

4. Ada kesalahan (schuld).

Unsur kesalahan ini dapat dibuktikan oleh $(\mathrm{X})$ dengan menyatakan bahwa tindakan yang dikerjakan oleh (Y) telah mengakibatkan kerugian.

Dengan demikian, pengobat tradisionl (Y) dapat digugat secara perdata berdasarkan perbuatan melawan hukum, karena unsur-unsur dari perbuatan melawan hukum tersebut telah terpenuhi. Korban (X) dapat menuntut ganti rugi berdasarkan perbatan melawan hukum kepada pengobat tradisional (Y) sesuai dengan Pasal 1365 KUHPerdata. Seperti yang sudah dijelaskan sebelumnya bahwa pelaku usaha (Y) yang sudah memberikan ganti rugi, dan telah di cari jalan damai maka pelaku usaha (Y) tidak lagi di pidana karena kasusnya telah dicari jalan penyelesaiannya.

Mengenai kegiatan usaha pengobat tradisional memang sejak awal pelaku usaha (YY) sudah tidak memiliki itikad baik untuk menjalankan kegiatan praktik pengobatan tradisionalnya. Permasalahan ini sudah terlihat di mana (YY) yang belum melakukan proses pengurusan perizinan praktik usaha tetapi sudah menyebarkan kegiatan usahanya lewat orang lain melalui mulut kemulut dan juga telah menjalankan praktik pengobatan. Jelas di sini, bahwa (YY) memang tidak melakukan kewajibannya sesuai ketentuan Pasal 7 UUPK, di mana ia tidak memiliki itikad baik dalam melakukan kegiatan usahanya dan tidak memberikan informasi yang benar, jelas, dan jujur mengenai kondisi dari jasa pengobatannya. Sedangkan, berdasar pada Pasal 4 UUPK, (XX) selaku konsumen pemanfaat jasa pengobatan tradisional memiliki hak atas kenyamanan, keamanan, dan keselamatan dalam mengkonsumsi barang dan/atau jasa, hak untuk memilih barang serta mendapatkan barang-barang tersebut sesuai dengan nilai tukar dan kondisi serta jaminan yang dijanjikan, hak untuk atas informasi barang yang benar dan jelas dan jujur mengenai kondisi dan jaminan atas barang dan/atau jasa yang dibelinya, akan tetapi hak-hak itu tidak diperolehnya secara penuh dari pelaku usaha (YY).

Di sinilah permasalahan yang sering memunculkan terjadinya sengketa antara konsumen dan pelaku usaha, di mana antara kepentingan konsumen berbenturan dengan kewajiban dari pelaku usaha. Permasalahan yang muncul dari kelalaian yang dilakukan oleh pelaku usaha/pengobat tradisional (YY) adalah terkait dengan:

1. Masalah periklanan yang berkaitan dengan isi Pasal 10 Undang- undang Perlindungan Konsumen, di mana diterangkan dalam ketentuan tersebut pelaku usaha dalam menawarkan barang dan/atau jasa yang ditujukan untuk diperdagangkan dilarang menawarkan, mempromosikan, mengiklankan atau membuat pernyataan yang tidak benar atau menyesatkan mengenai kondisi, tanggungan, jaminan, hak atau ganti rugi atas suatu barang dan/atau jasa. Namun, dalam kasus ini pelaku usaha (YY) sudah menyebarkan tempat usaha dan jenis usahanya lawan masyarakat yang satu kepada yang lainnya dengan menawarkan sesuatu yang dapat menyesatkan konsumen, karena tidak memberitahukan kondisi yang sebenarnya bahwa pelaku usaha/pengobat 
tardisional. Hal ini tentu sudah melanggar ketentuan Pasal 10 huruf c, di mana pelaku usaha/pengobat tradisional (YY) tidak memberitahukan kondisi sebenarnya yang dapat membawa dampak menyesatkan bagi konsumen.

2. Mengenai perizinan tempat praktik pengobatan pelaku usaha/pengobat tradisional (YY), di mana ia sudah membuka tempat praktik dan menerima konsumen padahal belum melakukan proses perizinan dari Dinas Kesehatan Kabupaten Pesisir Selatan.

3. Sedangkan untuk pertanggungjawaban pelaku usaha, dapat dilihat dalam Pasal 19 Undang-undang Perlindungan Konsumen, di mana terhadap kasus ini dapat dikualifikasikan secara perdata dan pidana. Tanggung jawab pelaku usaha pengobatan tradisional (YY) yang melakukan kelalaian dalam praktik usahanya hanya sebatas apa yang telah ditetapkan dalam Pasal 19 Undang-undang Perlindungan Konsumen, yakni berupa tanggung jawab secara perdata dan secara pidana, di mana konsumen yang merasa dirugikan (XX) dapat meminta ganti rugi dalam bentuk, pengembalian uang atau pengantian barang dan/atau jasa yang sejenis atau setara nilainya, atau perawatan kesehatan dan/atau pemberian santunan. Terhadap tanggung jawab pidananya, pemberian sejumlah ganti rugi tersebut ternyata tidak menghapuskan kemungkinan adanya tuntutan pidana yang berdasarkan pada pembuktian mengenai unsur kesalahannya. Sehingga korban (XX) masih dapat menuntut secara pidana ke pelaku usaha (YY), walaupun ia sudah menerima ganti rugi berupa pengembalian uang jasa yang setara nilainya.

Pengobatan tradisional di Nagari Surantih Kecamatan Sutera sudah lama berkembang namun belum ada yang memiliki izin pendirian tempat pengobatan, sehingga pernah terjadi beberapa kasus. Dari dua kasus diatas maka dapat diketahui dalam penyelesaian kasus pengobatan tradisional di nagari Surantih Kecamatan Sutera dalam penyelesaian kasusnya masih bisa di cari jalan damai lewat pemerintahan nagari.

\section{B. Pengawasan Pemeritah Terhadap Pengobatan Tradisional Tanpa Izin Di Nagari Surantih}

Pengawasan dan Pembinaan oleh pemerintah atas penyelenggaraan perlindungan konsumen sebagaimana dimaksud Pasal 1 dilaksanakan oleh menteri dan/atau menteri teknis terkait. Adanya keterlibatan pemerintah dalam pembinaan dan penyelenggaraan perlindungan konsumen berdasarkan ketentuan Pasal 29 UUPK, didasarkan pada kepentingan yang diamanahkan oleh pembukaan Undang-Undang Dasar 1945 bahwa kehadiran negara untuk mensejahterahkan rakyat.

Didalam pengawasan terhadap peredaran obat tradisional berbahan kimia/zat berbahaya selain pemerintah ada juga Badan Perlindungan Konsumen Nasional (BPKN), LPKSM serta masyarakat yang kemudian turut ambil bagian didalamnya diatur dalam UUPK Pasal 30. Yang dimana apabila diperhatikan secara seksama pasal ini tampak bahwa pengawasan lebih banyak menitipberatkan pada peran masyarakat dan LPKSM, dibanding dengan pemerintah yang pelaksanaannya dilakukan oleh menteri dan/atau menteri teknis yang terkait. Pengawasan menuntut upaya pemberian pemahaman dari peningkatan kesadaran yang menjadi hak konsumen, dan itu bukanlah sesuatu yang mudah bagi LPKSM dan masyarakat. Setelah lahirnya Peraturan Pemerintah Nomor 58 Tahun 2001 tentang Pembinaan. 
Pengawasan dan Penyelenggaraan Perlindungan Konsumen, bahwa ketidakjelasan peran pemerintah yang seolah hanya menyerahkan tugas pengawasan kepada masyarakat dan LPKSM sebagaimana yang telah disebutkan dalam Pasal 30 UUPK. Kini menjadi jelas, oleh karena dalam peraturan ini pemerintah telah ikut aktif melakukan pengawasan sebagaimana masyarakat dan LPKSM walaupun dengan objek pengawasan yang sedikit berbeda. Untuk mewujudkan tujuan UUPK, pemerintah bertanggung jawab atas pembinaan penyelenggaraan perlindungan konsumen (Pasal 29 ayat (1) UUPK). Dalam hal ini menteri yang ruang lingkup tugas dan tanggung jawabnya meliputi bidang perdagangan dan/atau menteri teknis terkait lainnya (Pasal 29 ayat (2) jo. Pasal 1 butir 13 UUPK) adalah Menteri Perdagangan.

Dari 2 kasus diatas ppihak pemerintah seperti Wali Nagari dan Kepala Kampung melakukan penyelidikan dengan memanggil kedua pihak untuk dimintai keterangan. Kemudian dilanjutkan dengan proses penyelesaian kasus dengan cara meminta pihak (X) untuk menyampaikan keluhan yang dirasakan dan kemudian meminta pihak (Y) untuk menanggapi dan memberi solusi atas kelalaian dalam pengobatan yang telah dilakukannya. Pihak (Y) merasa telah telah melakukan pengobatan sesuai dengan yang seperti biasa dilakukan, (Y) merasa pengobatan yang dilakukan sama dengan pengobatan yang selama ini dilakukan dan belum pernah ada kejadian apa pun. Setelah terjadi perdebatan maka diambil solusi oleh pihak pemerintah bahwa yang dilakukan Pihak (Y) salah karena izin dari pengobatan tersebut tidak ada dan telah merugikan pihak (X) maka pihak (Y) harus mengurus izin kembali dan harus mengembalikan uang yang telah diberikan kepadanya kepada pihak (X). Pihak (Y) menyetujui mengganti atas kelalaian yang telah dilakukan.

Pengawasan pemerintah nagari surantih terhadap perlindungan pengobatan tradisional telah dilakukan dengan cara mengawasi dan meninjau jika ada pelanggaran yang dilakukan oleh Jasa pengobatan tradisional, seperti memberikan perdamaian terhadap masalah yang terjadi antara pelaku usaha dengan penerima. Seperti yang terjadi pada kasus diatas yang mana pelaku usaha melakukan kesalahan sehingga penerima jasa menuntut dan meminta pertanggung jawaban, dengan adanya pengawasan pemerintah sehingga permaslahan tersebut bias diatasi dan tidak samapai di meja hukum/ pengadilan.

\section{Manfaat dan Dampak Pengobatan Tradisional Terhadap Masyarakat Nagari Surantih}

Penegakan hukum atau kasus peredaran obat tradisional berbahan kimia/zat berbahaya belum berjalan optimal, sehingga membuat pelaku usaha dalam melakukan aksinya bisa secara leluasa. Produsen dan distributor obat tradisional merupakan pelaku usaha yang bertanggung jawab terhadap obat tradisional yang beredar di pasaran. Untuk menghadapi persaingan yang sangat ketat pada era globalisasi saat ini, terkadang pelaku usaha obat tradisional melakukan tindakan-tindakan yang menghalalkan segala cara dengan melakukan berbagai pelanggaran dalam memproduksi obat tradisional.

Hal ini dilakukan agar mendapat keuntungan yang sebesar-besarnya tanpa memperhatikan kesehatan dan keselamatan jiwa konsumen. BPOM telah mengeluarkan kebijakan melalui peringatan public warning Nomor: HK.00.01.43.2773 tertanggal 2 Juni 2008 tentang Pelarangan peredaran 54 merek produk obat tradisional yang dicampur 
dengan bahan kimia berdasarkan hasil pengawasan obat tradisional melalui sampling dan pengujian laboratorium yang diambil dari 16 kota sepanjang tahun 2007. Menurut kepala BPOM Pusat, Husniah Rubiana Thamrin Akib, 54 merek jamu tersebut terdiri dari obat kuat, pegal linu, penambah keperkasaan pria, asam urat dan pelangsing yang seluruhnya terbukti mengandung zat kimia berbahaya seperti sibutramin hidroklorida, sildenafil sitrat, siproheptadin, fenilbutason, asam mefenamat, prednisone, metempiron, teofilin, dan parasetamol. Zat-zat kimia tersebut dapat meningkatkan tekanan darah tinggi, denyut jantung, dan sulit tidur, selain itu dapat juga memicu sakit kepala, mual, muntah, diare, anemia, gagal ginjal, nyeri gangguan penglihatan hingga kematian. Di antara 54 merek obat tradisional yang dilarang beredar, 46 produk menggunakan registrasi fiktif yang keberadaan alamatnya sulit dilacak dan ketujuh merek lainnya 1 (satu) diantaranya produk impor dan 6 (enam) lainnya produk lokal sehingga izin edarnya dicabut.

Dari keterangan diatas, dapat diketahui bahwa ada beberapa bentuk- bentuk pelanggaran yang dilakukan oleh pelaku usaha yang tidak bertanggung jawab, yaitu:

a. Memproduksi obat tradisional yang tidak memenuhi standar dan/atau persyaratan dengan mencampur obat tradisional dengan zat-zat kimia berbahaya;

b. Memproduksi obat tradisional yang tidak sesuai dengan produk yang didaftarkan di BPOM;

c. Mencantumkan nomor registrasi fiktif pada kemasan produk yang dibuat sehingga keberadaan alamatnya sulit dilacak;

d. Mencampurkan obat yang sudah kadaluarsa ke dalam obat tradisional yang diedarkan sehingga obat tradisional yang diperdagangkan berasal dari bahan-bahan berbahaya;

e. Menggunakan kemasan obat tradisional dengan gambar- gambar yang seronok, dan tulisan yang hiperbolis.

Pengobatan tradisional yang beredar pada nagari surantih cukup berkembang dan sangat bermanfaat bagai masyarakat seperti:

1. Dapat lebih mempermudah masyarakat cepat dalam penangana penyakit

2. Tidak perlu mengeluarkan biaya yang banyak, terutama bagi masyarakat yang memiliki ekonomi sengat minim.

3. Begitu juga dengan adanya pengobatan tradisional masyarakat nagari surantih bias dengan mudah mendapatkan obat.

Namun pengobatan tradisional juga berdampak pada masyarakat, seperti:

1. Pengobatan tidak memiliki izin sehingga tidak memiliki standar pengobatan dan belum teruji, walau sudah lama berkembang dan tidak ada pengawasan dari dinas kesehatan sehingga dapat menimbulkan penyakit lain seperti kasus diatas

2. Pengobatan yang dilakukan belum teruji sehingga dapat berdampak bagi kesehatan, seperti bahan yang digunakan cara pengolahan dan yang lainnya seperti kasus diatas yang mana dalam meracik ramuan tidak sesuai sehingga menimbulkan penyakit lain akibat ramuan tersebut.

3. Pengobatan tradisional juga dapat berdanpak bagi masyarakat apabila pengobatan belum teruji seperti dalam menangani kasus diatas patah tulang, jika belum memiliki standar yang baik dalam menangani patah tulang tersebut dapat berdanpak kepada penderita seperti tulang membusuk dan lain sebagainya. 


\section{KESIMPULAN}

1. Perlindungan hukum terhadap konsumen adalah segala upaya yang menjamin adanya kepastian hukum untuk memberi perlindungan kepada konsumen dan diharapkan dapat dijadikan sebagai benteng untuk meniadakan tindakan sewenang-wenang yang merugikan pelaku usaha hanya demi untuk kepentingan perlindungan konsumen. Kewenangwenangan akan mengakibatkan ketidakpastian hukum. Dari penelitian ini dapat disimpulkan bahwa perlinndungan konsumenn belum dilakukan seperti pelaku usaha belum memiliki izin oleh dinas kesehatan dan belum memiliki standar pengobatan yang baik.

2. Pengawasan Pemerintah Nagari Surantih terhadap perlindungan pengobatan tradisional telah dilakukan dengan cara mengawasi dan meninjau jika ada pelanggaran yang dilakukan oleh Jasa pengobatan tradisional, seperti memberikan perdamaian terhadap masalah yang terjadi antara pelaku usaha dengan penerima. Namun kelemahan dari pemerintah tidak menyarankan dan memaksa pelaku pengobatan tradisional untuk cepat melakukan pengurusan izin agar pengobatannya memiliki standar pengobatan yang benar dari dinas kesehatan setempat.

3. Pengobatan tradisional sangat bermanfaat bagi masyarakat karena dengan adanya pengobatan tradisional masyarakat dapat berobat dengan biaya yang sangat murah dan sudah banya terbukti pengobatannya ampuh dan ramuan yang digunakan sangat aman, namun dampaknya juga ada seperti kasus yang telah dijelaskan diatas yang mana pasien/ penderita merasa pengobatan yang dilakukan tambah membuat penyakitnya berkembang dan bahkan penyakit lain pula yang dirasakannya.

\section{DAFTAR PUSTAKA}

\section{Buku-Buku}

Asmino, P. Pengalaman Peribadi dengan Pengobatan Alternatif. Airlangga University Press. Jakarta. 1995.

Bambang sugono, Metode Penelitian Hukum, Rajawali Pers, Jakarta, 2013

Janus Sidabalok, Hukum Perlindungan Konsumen di Indonesia, Penerbit PT Citra Aditya Bakti, Bandung, 2010.

Dirjen POM RI. Petunjuk Pelaksanaan Pembuatan Obat Tradisional Yang Baik (CPOTB). Departemen Kesehatan Republik Indonesia. Jakarta, 1994.

Rahayu, Pengangkutan Orang, etd.eprints.ums.ac.id. Peraturan Pemerintah RI, 2009

Moleong, Lexy J.. Metodologi Penelitian Kualitatif. Bandung: Rosda Karya (2010)

Nasution, Az. Aspek Hukum Perlindungan Konsumen: Tinjauan Singkat UUNomor 8 Tahun 1999-LN. 1999 No. 42. Depok: Masyarakat Pemantau Peradilan Indonesia (MAPPI) FHUI. 


\section{Peraturan Perundang-Undangan}

Undang-Undang Nomor 8 Tahun 1999 Tentang Perlindungan Konsumen. Undang-Undang Nomor 18 Tahun 2012 Tentang Pangan.

Undang-undang Republik Indonesia No. 23 tahun 1992 tentang Kesehatan. (1992). Jakarta: Depkes RI

Peraturan Pemerintah Nomor 69 Tahun 1999 Tentang Label dan Iklan Pangan.

Peraturan Pemerintah No.58 Tahun 2001 Tentang Pembinaan dan Pengawasan Penyelenggaraan Perlindungan Konsumen.

Departemen Kesehatan, Keputusan Menteri Kesehatan tentang Penyelenggaraan Pengobatan Tradisional, Kepmenkes No. 1076/Menkes/SK/VII/2012.

Indonesia, Undang-Undang Tentang Kesehatan, UU No. 23 Tahun 1992, LN No. 100 Tahun 1992, TLN No. 3495. Indonesia, Undang- Undang Tentang Perlindungan Konsumen, UU No. 8 Tahun 1999, LN No. 42 tahun 1999, TLN No. 3821

\section{Internet}

Pelayanan Pengobatan www.sijorimandiri.net/jl/index.php. 24 Juli 2019.

Rachmad Puageno, Quo Vadis Pengobatan Tradisional www.puageno.multiply.com/journal/item/7 29 Juli 2018.

Tradisional. Indonesia, Sabarudin Juni. Perlindungan Hukum Terhadap Konsumen Dilihat Dari Segi Kerugian Akibat Barang Cacat dan Berbahaya. http://library.usu.ac.id/modules.php . 23 Maret 2020. 